\title{
Hydraulic resistance partitioning between shoot and root system and plant water status of Haloxyolon ammodendron growing at sites of contrasting soil texture
}

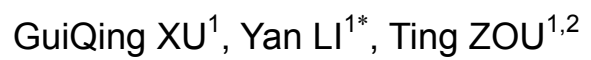 \\ ${ }^{1}$ Fukang Station of Desert Ecology and Key Laboratory of Oasis Ecology and Desert Environment, Xinjiang Institute of Ecology \\ and Geography, Chinese Academy of Sciences, Urumqi 830011, China; \\ ${ }^{2}$ Graduate University of Chinese Academy of Sciences, Beijing 100049, China
}

\begin{abstract}
Hydraulic resistance components and water relations were studied on Haloxyolon ammodendron, a small xeric tree, growing at sites significantly differed in soil texture. Soil water content, leaf water potential $\left(\psi_{1}\right)$, xylem water potential $\left(\psi_{\mathrm{x}}\right)$, root water potential $\left(\psi_{\text {root }}\right)$, leaf transpiration rate $(T R)$ and stomatal conductance $\left(\mathrm{g}_{\mathrm{s}}\right)$ were measured at the two sites during the growing season of 2005 and 2006. Leaf specific hydraulic resistance $\left(R_{\text {plant }}\right)$ during the whole growing season, hydraulic resistance of plants $\left(R_{p}\right)$, shoots $\left(R_{\text {shoot }}\right)$ and roots $\left(R_{\text {root }}\right)$ in the August of both years were calculated and expressed on leaf area basis. The results showed the proportion of the hydraulic resistance of the aerial part $\left(R_{\text {shoot }}\right)$ to the $R_{p}$ was the same to the proportion of the hydraulic resistance of the soil part $\left(R_{\text {root }}\right)$ to the $R_{p}$, indicating that both parts were equivalent important to plant water hydraulic system from soil to leaf. Positive significant correlations were found between $R_{p}$ and $R_{\text {root }}$, suggesting that root hydraulics resistance was a major determinant of plant hydraulic resistance $\left(R_{p}\right)$ and transpiration rate. The integrated effect of stomatal control, hydraulic regulation and morphology adjustment enabled plants at heavy soil site surviving the extreme water deficit period.
\end{abstract}

Keywords: hydraulic architecture; leaf water potential; transpiration; hydraulic resistance; stomatal conductance; hydraulic limitation

\section{Introduction}

The hydraulic architecture of a plant first coined by Zimmermann (1978), which refers to the partitioning of hydraulic conductance in a plant and includes changes in xylem efficiency and vulnerability to cavitations (Zimmermann 1978; Zimmermann and Sperry, 1983; Tyree and Ewers, 1991a). Tyree (2007) defined the terminology as a quantitative description of the plant in terms of the Ohm's law analog using a simple linear model of conductance elements or a complex branched catena of a few or even thousands of conductance elements. Hydraulic architecture is an important determinant of the plant water balance, and influences plant water relations and growth potential (Sperry, 2000; Meinzer, 2002). Environmental variables have shown to influence hydraulic archi- tecture extensively. Soil water limiting, for example, promotes plants investing more biomass to below ground and thus alters the corresponding absorption-transport-transpiration cross-sectional area ration, which in sequence change the organs and individual specific hydraulic conductance (Ewers et al., 2000; Hacke et al., 2000; Li et al., 2005; Addington et al., 2006). Furthermore, nutrient and water deficiency lead to plant morpho-functional adjustment and alter hydraulics conductance to facilitate nutrient and water capture (Ewers et al., 2000; Trubat et al., 2006). Nitrogen fertilization has shown to increase leaf area production (Albaugh et al., 1998), thereby decreasing both root-leaf surface area ratio and sapwood-

Received 2010-03-11, accepted 2010-04-02

doi: 10.3724/SP.J.1227.2010.00098

* Corresponding author: Yan LI (E-mail: Liyan@ms.xjb.ac.cn) 
leaf area ratio. Additionally, the reduction of irradiance and light regimes also influence hydraulic architecture and water relations (Tyree et al., 1998; Hernández et al., 2009; Raimondo et al., 2009).

The partitioning of hydraulic resistance or its reciprocal, conductance, along the water transport path was one of the important factors of hydraulic architecture (Zimmermann, 1978; Zimmermann and Sperry, 1983; Tyree et al., 1991b; Cruiziat et al., 2002). The evolutional, adaptive and responsive significance of hydraulic separations prevailing environmental factors had been given extensively attention since the hydraulic architecture concept introduced by Zimmermann (1978), especially on hydraulic resistance coordination among organs changes (Nardini et al., 1998, 1999b, 2003; Tyree et al., 1999; Aranda et al., 2005). Hydraulic resistance was an important factor in predicting plant water status (Iro et al., 1995), characterizing the drought resistance ability of plants (Nardini, 1998, 1999a; Trifilò et al., 2004), and explaining competitive advantage among plant species (Nardini, 1998; Triflò, 2004). Plant growth rate and biomass production were also closely related to plant hydraulic conductance (Nardini, 1999b; Solari, 2006). Newly advance of resistances partition had been carried out at finely organs to tissues levels, such as changes in the conductance to water of the vascular and non-vascular compartment of roots and leaves (Amodeo, 1999; Salleo et al., 2003) and on micro-time scales, such as circadian regulation of leaf and root hydraulic conductance (Henzler 1999; Nardini, 2005).

Soil texture is particularly important to plant and soil water relations in arid systems (Alizai and Hubert, 1970; Noy-Meir, 1973). Due to higher saturated conductivity (Jury et al., 1991), smaller capillary water in topsoil and less tightly bound to particles, sandy soil have a greater soil water potential than a clay soil in the period of relative higher soil water content following rain pulse in desert ecosystem (Nilsen and Orcutt, 1996). However, it declines quickly with prolonged drought. Plants may overcome the effects of steeply declining soil hydraulic conductivity at high soil water potential by developing higher root to leaf area ratios, or by lowering the transpiration rate (Hacke et al., 2000; Xu and Li, 2008). Both features will alter the plants hydraulic traits above and below ground thus preventing the loss of hydraulic contact between the root system and the soil (Sperry et al., 1998, Hacke et al., 2000). Furthermore, higher porosity in coarse textured soil than in fine textured soil facilitated root-soil air gaps formation at drying period which could benefit desert plant by maintaining a higher root water potential in the early stages of drought, and later by limiting root water loss at the root-soil interface when the water potential exceeds that of soil (North and Nobel, 1997). Despite the influence of soil texture on hydraulic traits and plant water relations has been extensively studied, scarce research pay attention to the hydraulic resistance distribution and adjustment in relation to soil texture change and corresponding variation of soil water availability. Hydraulic separations and changes between organs would allow plants to favor certain parts at the expense of others especially for plants undergoing prolonged drought, which may mirror the plant water use strategy.

Haloxylon ammodendron (C.A.Mey.) Bunge is a sub-tree xerophilous plant that is native to a variety of Central Asian and African desert habitats, including gravel desert, heavy-textured desert soil, and sandy desert. The leaves of $H$. ammodendron have retrogressed as succulent branches and showed a $\mathrm{C}_{4}$ type of photosynthesis (Pyankov et al., 1999). Previous research on $H$. ammodendron in different soil texture have integrated morphology and physiology traits, and investigated the traits performance under nature and artificial water conditions with the aim to better understanding their response to drought at different scales (Xu and Li, 2008; Zou et al., 2009). In this paper we aimed to clarify the difference and consistency of plant water status and hydraulic resistance partitioning of aerial part versus underground part in $H$. ammodendron growing at different soil habitats and quantify the contribution of resistance in root and shoot to the whole plant resistance.

\section{Materials and methods}

\subsection{Plant materials and growing conditions}

Field experiments were carried out during the growing season of 2005 and 2006 at Fukang Station of Desert Ecology, Chinese Academy of Sciences, which is in the hinterland of Eurasia $\left(44^{\circ} 17^{\prime} \mathrm{N}, 87^{\circ} 56^{\prime} \mathrm{E}, 475 \mathrm{~m}\right.$ above sea level). The plain area of this region has a 
continental arid temperate climate, with a hot dry summer and cold winter. Annual mean precipitation is about $160 \mathrm{~mm}$. Annual pan evaporation is about 1,000 $\mathrm{mm}$. H. ammodendron is a major dominant species of the region and is highly drought and salt-tolerant. Studies were conducted at two $H$. ammodendron habitats of contrasting soil textures with similar climatic conditions (less than $8 \mathrm{~km}$ apart). One site was at the edge of a sandy desert with a sandy soil (referred to as sandy hereafter, $44^{\circ} 22^{\prime} \mathrm{N}, 87^{\circ} 55^{\prime} \mathrm{E}, 448 \mathrm{~m}$ above sea level); the other site was at the fringe of an alluvial plain with a heavy textured soil (referred to as heavy hereafter, $44^{\circ} 14^{\prime} \mathrm{N}, 87^{\circ} 51^{\prime} \mathrm{E}, 454.5 \mathrm{~m}$ above sea level). The sites were far from direct human influence. Average height and canopy radius was $1.77 \pm 0.10 \mathrm{~m}$ and $1.41 \pm 0.14 \mathrm{~m}$ for sandy soil site; and $1.70 \pm 0.10 \mathrm{~m}$ and $1.05 \pm 0.11 \mathrm{~m}$ for heavy textured soil site.

\subsection{Measurement of soil water moisture and rain- fall}

Soil particle sizes were measured with a laser diffraction system in the laboratory on soil samples taken from experiment sites (Sympatec $\mathrm{GmbH}$, System-Partikel-Technik, Clausthal-Zellerfeld, Germany). The sampling depth was from soil surface to $400 \mathrm{~cm}$ with interval of $20 \mathrm{~cm}$. The soil water content was measured during growing season at two sites every five days at depths of $0-20 \mathrm{~cm}, 20-40 \mathrm{~cm}, 40-60 \mathrm{~cm}$, 60-80 cm, 80-100 cm, 100-120 cm, 120-140 cm and $140-160 \mathrm{~cm}$ with five replicates, by oven-drying and weighing. A portable meteorological station (Campbell Scientific, Logan, Utah, US) installed between the two sites, and meteorological data was collected.

\subsection{Gas exchange and plant water status}

The leaf transpiration rate (TR) was measured by the compensated heat-pulse system of Cohen et al. (1983). Ten heat-pulse probes were installed for each site on branches of diameter of $8-15 \mathrm{~mm}$, and the sap flow rate for each branch (TR of the branches) recorded every $30 \mathrm{~min}$. To overcome the effect of variation in branch size, the TR value was normalized on a leaf-area basis. To quantify leaf area of each branch, all foliage on each selected branch was photographed every two weeks with a $6 \times 10^{8}$ pixel digital camera (Canon 300D, Canon Inc, Tokyo, Japan). The leaf surface area of each branch was calculated from the photographs using CI-400 CIAS software (ComCID
Co, Logan, UT, US). The TR value was then converted to a leaf-specific value according to the leaf surface area of each branch. A steady-state porometer (Model LI-1600; LI-COR, Lincoln, NE, US) was used to determine stomatal conductance $\left(\mathrm{g}_{\mathrm{s}}\right)$. Ten replicates were measured every hour on ten fixed, labeled leaves at each site. Leaf water potential $\left(\psi_{1}\right)$ was measured with Model 1000 pressure chamber (PMS Instrument Co., Albany, US). For each measurement 10 replicates were taken on 10 individual plants. For tracing diurnal $\psi_{1}$, measurements were done every $30 \mathrm{~min}$ at early and late afternoon, and every hour around noon. Predawn leaf water potential $\left(\psi_{\mathrm{pd}}\right)$ was measured $30 \mathrm{~min}$ before sunrise and midday leaf water potential $\left(\psi_{\mathrm{m}}\right)$ was measured at solar noon. The xylem water potential at trunk base $\left(\psi_{\mathrm{x}}\right)$ from predawn to sunset was estimated by covering four to five leaves growing near the base of plants with aluminum foil on the evening before the trial day. Under this condition, leaf water potential is generally equilibrium to the adjacent xylem (Nardini et al., 2003; Raimondo et al., 2009). Because of the limiting amount of sucker leaves, the measurement was performed only in August in both years.

The shallow layers soil $(0-1 \mathrm{~m})$ was removed and the roots were carefully exposed without damage. Target roots $(2-3 \mathrm{~mm}$ in diameter) were cut into segments with length of 4-6 cm, sealed with cyanoacrylate adhensive at one cut end and wrapped quickly with insulating tape. Measurement was completed within $3 \mathrm{~min}$ of excision. Due to the limitation of instrument and manpower, all the leaf and root water potential and stomata were measured alternatively: e.g. one day at sandy soil site, the next day at heavy textured soil site.

The impact of water stress on plants (WSIS) was expressed in the integrated form (Mishio and Yokoi, 1991; Vertovec et al., 2001):

$$
\text { WSIS }=\int_{t_{0}}^{t_{x}} \psi_{\mathrm{L}} \cdot d t,
$$

where WSIS is the impact of water stress on individuals of a given species and $d t$ is the time interval when $\Psi_{\mathrm{L}}$ (shoot water potential) measurements are performed. $t_{0}$ and $t_{x}$ are pre-dawn, and sunset times, respectively. Because the diurnal course of shoot water potential and transpiration rate showed that after 12:00 the both values were unstable, which inferred that there must exist other means of regulation, such as 
stomata adjustment or osmotic adjustment. Therefore $t_{x}$ was taken as 12:00 in the current study.

\subsection{Hydraulics measurement}

To estimate seasonal change in the hydraulic resistance of whole plant (leaf specific hydraulic resistance, $\mathrm{R}_{\mathrm{p}}$ ), diurnal $\psi_{1}$ was plotted against diurnal transpiration flux density (Cohen et al., 1983). The slope of the linear relationship is taken as the hydraulic resistance of the plant. The hydraulic resistance of aerial part and root system were calculated using the evaporative flux method (Nardini et al., 2003; Raimondo et al., 2009). Hydraulic resistance of whole plant $\left(R_{\text {plant }}\right)$, shoots $\left(\mathrm{R}_{\text {shoot }}\right)$ and roots $\left(\mathrm{R}_{\text {root }}\right)$ was calculated as:

$$
\begin{aligned}
& \mathrm{R}_{\text {plant }}=\left(\psi_{\mathrm{pd}}-\psi_{\mathrm{m}}\right) / \mathrm{E}_{\mathrm{L}}, \\
& \mathrm{R}_{\text {root }}=\left(\psi_{\mathrm{pd}}-\psi_{\mathrm{x}}\right) / \mathrm{E}_{\mathrm{L}}, \\
& \mathrm{R}_{\text {shoot }}=\left(\psi_{\mathrm{x}}-\psi_{\mathrm{m}}\right) / \mathrm{E}_{\mathrm{L}} .
\end{aligned}
$$

Where $\psi_{\text {pd }}$ is assumed to equilibrate to soil water potential; $\mathrm{E}_{\mathrm{L}}$ is maximum transpiration rate at noon; $\psi_{\mathrm{x}}$ is the xylem water potential at trunk base. All of the hydraulic resistances were expressed on leaf area basis.

\subsection{Data analysis}

Descriptive statistics were used to calculate mean and standard errors of the mean. Mean value of hydraulic parameters $\left(\psi_{\mathrm{pd}}, \psi_{\mathrm{m}}, \psi_{\text {root }}, \mathrm{g}_{\mathrm{s}}\right.$ and $\left.\mathrm{TR}_{\max }\right)$ were compared with student's t-tests at two sites. The Pearson product moment correlation was used for correlation analysis. All statistical analyses were performed using Minitab 15. Charting used the mapping software origin 8.0 (Origin Lab. Corp., Northampton, MA, USA.).

\section{Results}

\subsection{Soil particle composition and soil water mois- ture}

The particle size was $0-500 \mu \mathrm{m}$ for the sandy soil and 0-50 $\mu \mathrm{m}$ for the heavy textured soil. The data of soil particle composition indicating no significance difference by t-tests at variation soil depth intervals were pooled together. Therefore only the soil compositions of particle sizes at depth of 0-20 cm, 20-150 cm and $150-400 \mathrm{~cm}$ were given in Fig. 1.

The seasonal pattern of soil moisture changes in the profiles can be seen in Fig. 2. Influenced by precipitation, the surface layer $(0-20 \mathrm{~cm})$ soil water content fluctuated at the range of $1 \%$ to $7 \%$ in sandy soil and $4 \%$ to $16 \%$ in heavy textured soil. Except the surface layer, the soil water content showed little variation with the depth in sandy soil. However, there existed a high soil water moisture zone at $40-80 \mathrm{~cm}$ in heavy textured soil.

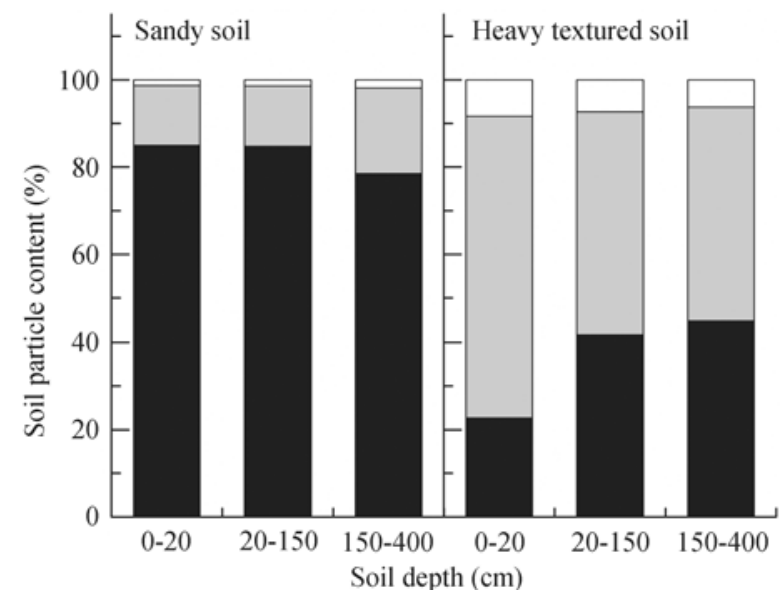

Fig. 1 Sand $\square$, silt $\square$, and clay $\square$ fractions for sandy soil and heavy textured soil at $0-20 \mathrm{~cm}, 20-150 \mathrm{~cm}$ and $150-400$ cm depth

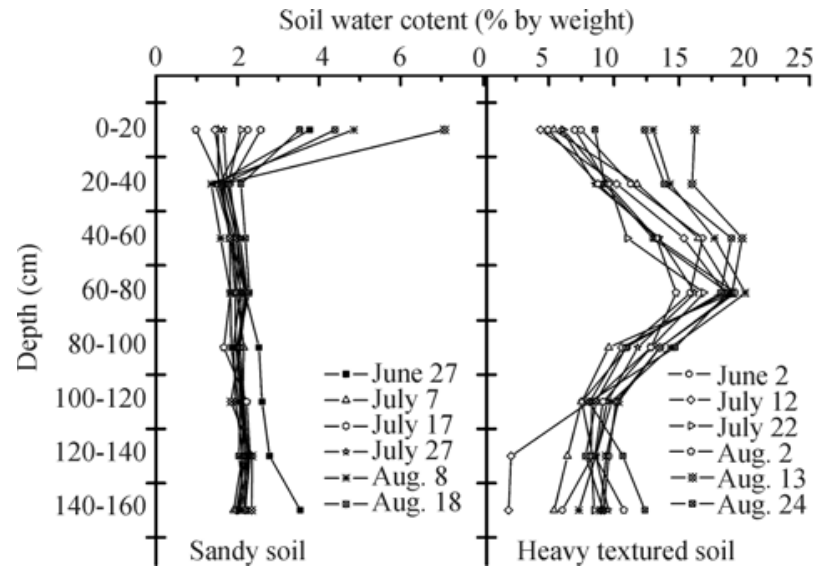

Fig. 2 Seasonal variation in soil water content along the soil profiles from 0 to $160 \mathrm{~cm}$ at interval of $20 \mathrm{~cm}$ in the growing season of 2005. Legend indicated the date of the year.

\subsection{Seasonal and diurnal changes in plant water status}

The seasonal variation of predawn $\left(\psi_{\mathrm{pd}}\right)$ and midday $\left(\psi_{\mathrm{m}}\right)$ leaf water potential and the occurring of precipitation were reported in Fig. 3. In both soil types, $\psi_{\mathrm{pd}}$ and $\psi_{\mathrm{m}}$ were affected by rain events, which were higher after rain and declined with prolonged drought. Mean midday-predawn water potential gradient in two growing season was $1.70 \pm 0.27 \mathrm{MPa}$ and $1.19 \pm 0.18$ MPa for sandy and heavy textured soils, respectively $(P<0.001)$. In heavy textured soil, the lowest water potential gradient appeared on 4 July 2005 and on 5 
August 2006, which were close to zero. The total rainfall in 2005 was $133.8 \mathrm{~mm}$ and $102.7 \mathrm{~mm}$ in 2006 . In August when the covered leaves (xylem water potential) measurements were done, the total rainfall was $35.7 \mathrm{~mm}$ in 2005 and $6.1 \mathrm{~mm}$ in 2006 .

The mean $\psi_{\mathrm{pd}}$ and $\psi_{\mathrm{m}}$ value of sandy soil in $2005 \mathrm{vs}$. 2006 was $-2.31 \pm 0.09 \mathrm{MPa}$ against $-2.52 \pm 0.08 \mathrm{MPa}$ $(P=0.124)$ and $-4.09 \pm 0.12 \mathrm{MPa}$ against $-4.19 \pm 0.06$ MPa $(P=0.498)$. The mean $\psi_{\mathrm{pd}}$ and $\psi_{\mathrm{m}}$ of heavy textured soil in 2005 vs. 2006 was $-3.14 \pm 0.18 \mathrm{MPa}$ against $-3.42 \pm 0.06 \mathrm{MPa}(P=0.171)$ and $-4.42 \pm 0.10$ $\mathrm{MPa}$ against $-4.56 \pm 0.06 \mathrm{MPa}(P=0.251)$. The averaged values of $\Psi_{\text {root }}, \Psi_{\mathrm{pd}}, \Psi_{\mathrm{m}}, \mathrm{g}_{\text {noon }}, \mathrm{TR}_{\mathrm{max}}$, and $\mathrm{R}_{\mathrm{p}}$ in two years were shown in Table 1. There were significant differences among $\psi_{\mathrm{pd}}$ and $\psi_{\mathrm{m}}$ in the two sites.
However, the $\Psi_{\text {root, }}, \mathrm{g}_{\text {noon }}, \mathrm{TR}_{\max }$ and $\mathrm{R}_{\mathrm{p}}$ showed no difference.

The calculated WSIS of each trial day were averaged for months (Fig. 4). The result showed WSIS increased from May to July and decreased in August in 2005. In 2006, the WSIS increased from June to September continuously. The WSIS was significantly different on different soil textures for the same month, except for August 2005.

The maximum transpiration $\left(\mathrm{TR}_{\max }\right)$ was plotted against the whole plant hydraulic conductance $\left(\mathrm{R}_{\mathrm{p}}\right)$ in the two sites (Fig. 5). There were good relationship between the $\mathrm{TR}_{\max }$ and $\mathrm{R}_{\mathrm{p}}$. $\mathrm{TR}_{\max }$, which declined with the increase of $R_{\text {plant }}$ indicating that the $\mathrm{TR}_{\max }$, which partially controlled by the $\mathrm{R}_{\mathrm{p}}$.

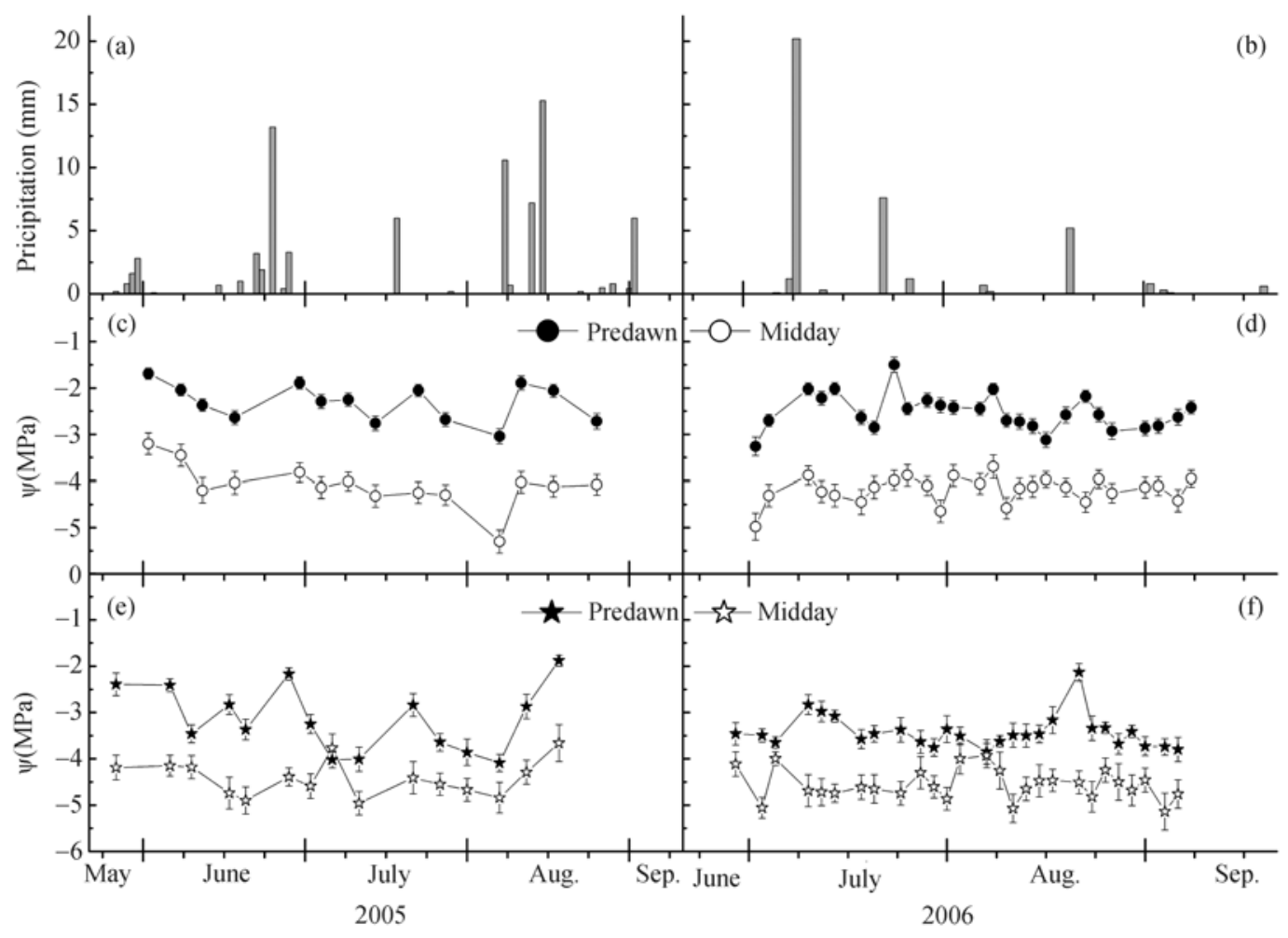

Fig. 3 Seasonal pattern of predawn and midday leaf water potential measured at sandy soil from 2005 (c) to 2006 (d) and at heavy soil from 2005 (e) to 2006 (f) with average value \pm S.E. Rainfall at the two experimental sites in 2005 (a) and 2006 (b) were also given.

Table 1 Comparison of the mean physiological parameters of $H$. ammodendron through the two growing season at two contrasting textured soils

\begin{tabular}{ccccccc}
\hline \multirow{2}{*}{ Sites } & $\Psi_{\text {root }}$ & $\Psi_{\mathrm{pd}}$ & $\Psi_{\mathrm{m}}$ & $\mathrm{g}_{\text {noon }}$ & $\mathrm{TR}_{\max }$ & \\
\cline { 2 - 6 } & $(\mathrm{MPa})$ & $(\mathrm{MPa})$ & $(\mathrm{MPa})$ & $\left(\mathrm{mmol} /\left(\mathrm{m}^{2} \cdot \mathrm{s}\right)\right)$ & $\left(\mathrm{mmol} /\left(\mathrm{m}^{2} \cdot \mathrm{s}\right)\right)$ & $\left(\mathrm{MPa} \cdot \mathrm{m}^{2} \cdot \mathrm{s} / \mathrm{mmol}\right)$ \\
\hline Sandy soil & $-1.2 \pm 0.02 \mathrm{a}$ & $-2.5 \pm 0.1 \mathrm{a}$ & $-4.0 \pm 0.2 \mathrm{a}$ & $40.1 \pm 2.6 \mathrm{a}$ & $3.9 \pm 0.2 \mathrm{a}$ & $0.56 \pm 0.03 \mathrm{a}$ \\
Heavy soil & $-0.96 \pm 0.03 \mathrm{a}$ & $-3.3 \pm 0.1 \mathrm{~b}$ & $-4.5 \pm 0.1 \mathrm{~b}$ & $46.5 \pm 3.2 \mathrm{a}$ & $3.7 \pm 0.2 \mathrm{a}$ & $0.47 \pm 0.03 \mathrm{a}$ \\
\hline
\end{tabular}

Values are means \pm S.E. within columns with different letters are significantly different at $P=0.05$ 


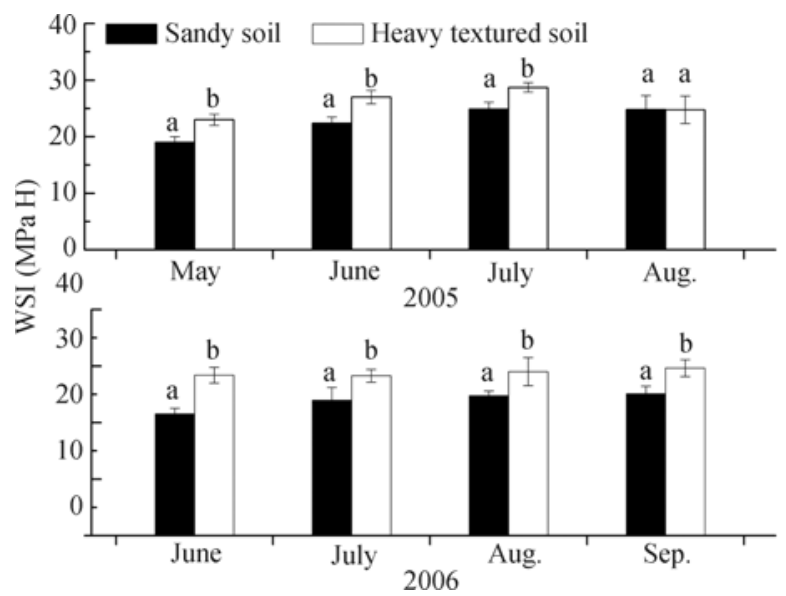

Fig. 4 Integration of the half-diurnal course of leaf water potential measured between predawn and midday was named as water stress index (WSIS). The WSIS of each trial day were averaged for months in 2005 to 2006 . The different letters mean significant differences at $P=0.05$. Vertical bars are $S$. E. of the mean.

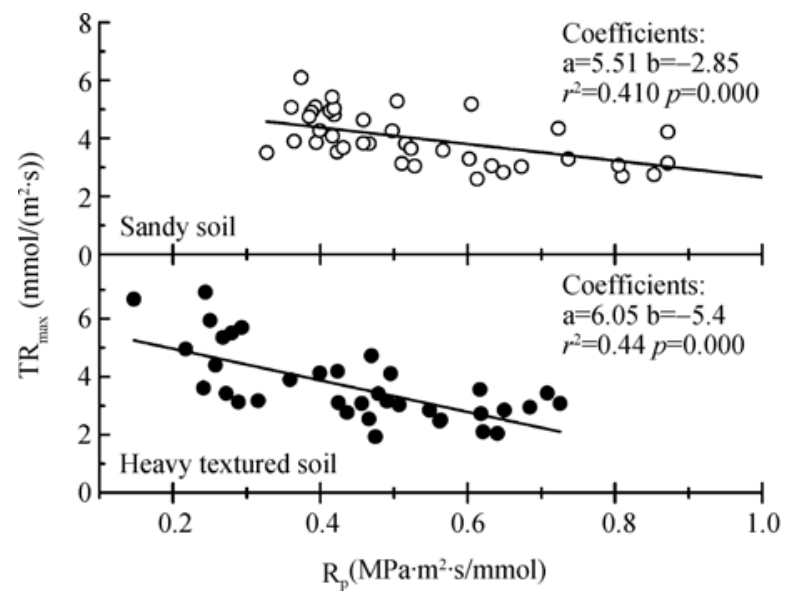

Fig. 5 The relationship between daily maximum transpiration rate $\left(T R_{\max }\right)$ and whole plant hydraulic resistance $\left(R_{p}\right)$ for sandy and heavy textured soils

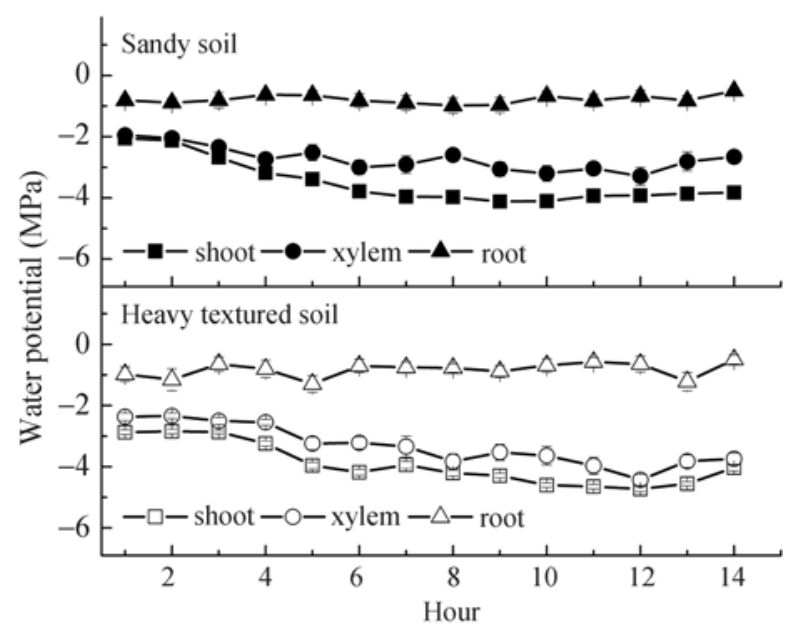

Fig. 6 The diurnal courses of water potential of shoot, xylem and root at sandy soil and heavy textured soil from dawn to sunset
Diurnal course of plant water potential from root to leaf was described in Fig. 6. Root water potential kept relative constant from predawn to sunset. The leaf and xylem water potential decreased from dawn to midday and increased at later afternoon. Water potential sequential descended from root to leaf in accordance with the water movement direction. The water potential gradient from root to xylem was narrower than that of xylem to leaf.

\subsection{Partitioning of hydraulic resistances}

The average plant hydraulic resistance $\left(\mathrm{R}_{\text {plant }}\right)$ and its components ( $\mathrm{R}_{\text {root }}$ and $\left.\mathrm{R}_{\text {shoot}}\right)$ in August of the two years were given in Fig. 7. There were no significant differences between $R_{\text {root }}$ and $R_{\text {shoot }}$ in the dry and wet August of the two years.

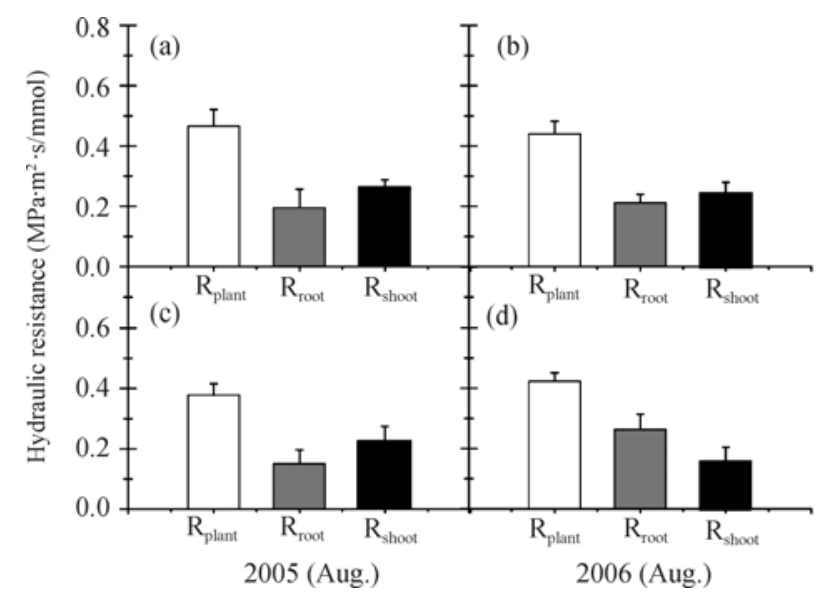

Fig. 7 Hydraulic resistance $(R)$ of the whole plant $\left(R_{\text {plant, }}\right.$ open

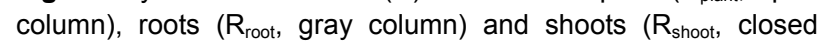
column) measured at the two sites in August of 2005 and 2006: (a) and (b) were in sandy soil, (c) and (d) were in heavy textured soil. The $R$ values were average \pm S.E. of the August with $n=4$ to 7 days average for each year.

However, comparing with the wet August, the $\mathrm{R}_{\text {root }}$ increased and $R_{\text {shoot }}$ declined in heavy textured soil in the dry August. The relationship between $R_{\text {root }}, R_{\text {shoot }}$ and $R_{\text {plant }}$ was described in Fig. 8, where all $R_{\text {root }}$ and $R_{\text {shoot }}$ values were plotted against corresponding $R_{\text {plant }}$ values. The results showed that there was good relationship between $\mathrm{R}_{\text {plant }}$ and $\mathrm{R}_{\text {root }}$. Comparison of average hydraulic parameters at two sites in August 2005 and 2006 were shown in Table 2. The predawn leaf water potential $\left(\Psi_{\mathrm{pd}}\right)$ and noon stomatal conductance $\left(g_{\text {noon }}\right)$ at 12:00 to14:00 were lower in 2006 vs. 2005 at each site. The midday leaf water potential $\left(\Psi_{\mathrm{m}}\right)$ and maximum transpiration rate $\left(\mathrm{TR}_{\max }\right)$ kept same. 


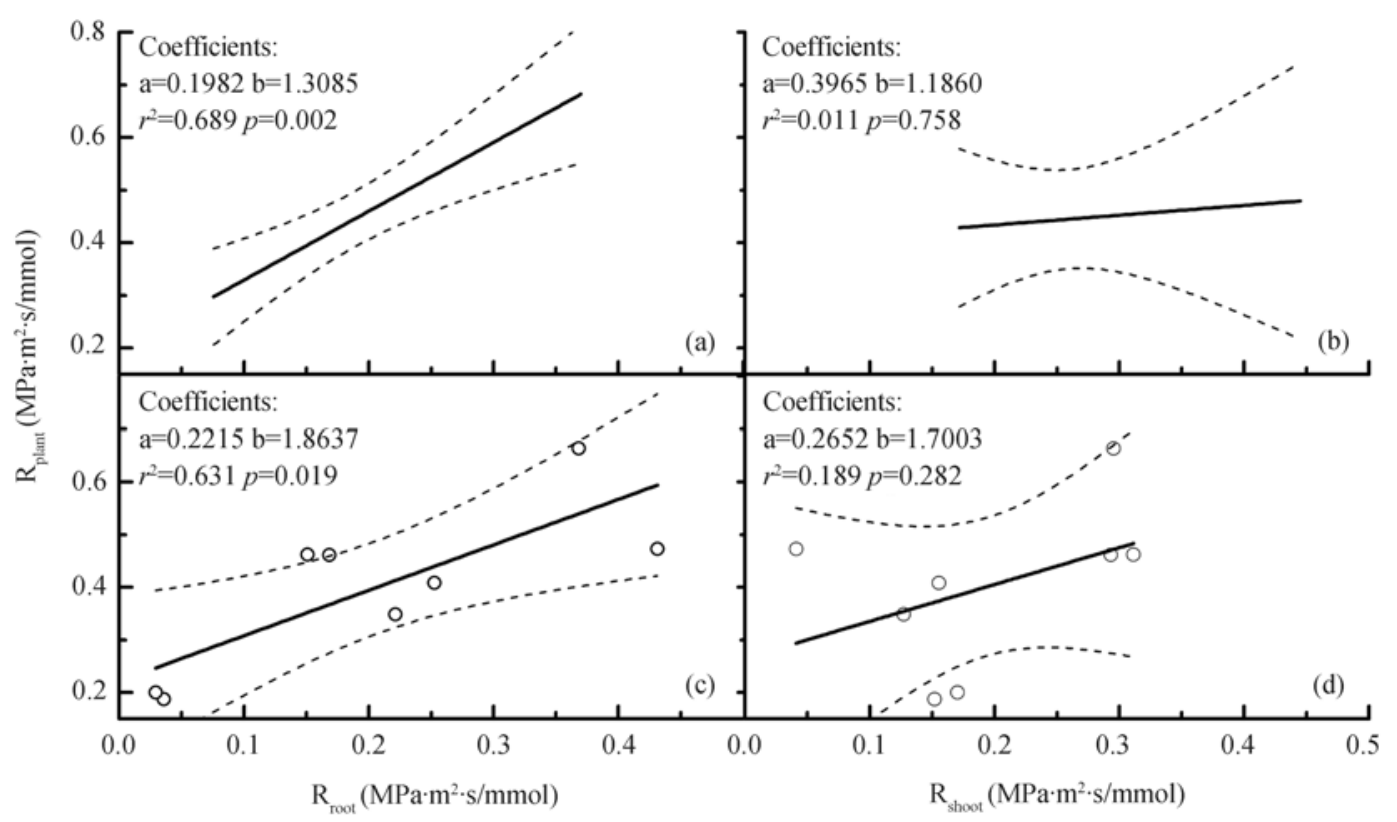

Fig. 8 Relationship between the hydraulic resistances of whole plant $\left(R_{\text {plant }}\right)$, roots $\left(R_{\text {roots }}\right)$ and shoots $\left(R_{\text {shoots }}\right)$ : $(a)$ and $(b)$ were in sandy soil, (c) and (d) were in heavy textured soil. The centre solid line is the linear regression and the dashed lines are $95 \%$ confidence intervals. The coefficients of the straight line are reported together with the coefficient of determination $\left(r^{2}\right)$ and the $P$ value (Pearson Product Moment Correlation).

Table 2 Comparison of the mean physiological parameters of $H$. ammodendron at two contrasting textured soils in August of the two growing seasons

\begin{tabular}{ccccccccc}
\hline Sites & \multicolumn{3}{c}{ August in 2005 } & \multicolumn{3}{c}{ August in 2006 } \\
\hline & $\begin{array}{c}\Psi_{\mathrm{pd}} \\
(\mathrm{MPa})\end{array}$ & $\begin{array}{c}\Psi_{\mathrm{m}} \\
(\mathrm{MPa})\end{array}$ & $\begin{array}{c}\mathrm{g}_{\text {noon }} \\
\left(\mathrm{mmol} /\left(\mathrm{m}^{2} \cdot \mathrm{s}\right)\right)\end{array}$ & $\begin{array}{c}\mathrm{TR}_{\max } \\
\left(\mathrm{mmol} /\left(\mathrm{m}^{2} \cdot \mathrm{s}\right)\right)\end{array}$ & $\begin{array}{c}\Psi_{\mathrm{pd}} \\
(\mathrm{MPa})\end{array}$ & $\begin{array}{c}\Psi_{\mathrm{m}} \\
(\mathrm{MPa})\end{array}$ & $\begin{array}{c}\mathrm{g}_{\text {noon }} \\
\left(\mathrm{mmol} /\left(\mathrm{m}^{2} \cdot \mathrm{s}\right)\right)\end{array}$ & $\begin{array}{c}\mathrm{TR}_{\max } \\
\left(\mathrm{mmol} /\left(\mathrm{m}^{2} \cdot \mathrm{s}\right)\right)\end{array}$ \\
\hline Sandy soil & $-2.2 \pm 0.2 \mathrm{a}$ & $-4.0 \pm 0.02 \mathrm{a}$ & $55.69 \pm 3.0 \mathrm{a}$ & $3.25 \pm 0.2 \mathrm{a}$ & $-2.7 \pm 0.1 \mathrm{a}$ & $-4.2 \pm 0.1 \mathrm{a}$ & $41.02 \pm 2.6 \mathrm{a}$ & $3.41 \pm 0.15 \mathrm{a}$ \\
Heavy soil & $-2.9 \pm 0.4 \mathrm{~b}$ & $-4.0 \pm 0.3 \mathrm{a}$ & $47.15 \pm 6.6 \mathrm{a}$ & $2.95 \pm 0.3 \mathrm{a}$ & $-3.4 \pm 0.1 \mathrm{~b}$ & $-4.6 \pm 0.1 \mathrm{~b}$ & $34.29 \pm 1.5 \mathrm{~b}$ & $3.01 \pm 0.16 \mathrm{a}$ \\
\hline
\end{tabular}

Values are means \pm S.E. within columns with different letters are significantly different at $P=0.05$

\section{Discussion and conclusion}

For the plants experience similar weather condition, the differences in soil properties (Fig. 1) appeared to have significantly affected on the water status of $H$. ammodendron. The target plants at sandy soil site had better water conditions than that of heavy soil site (Figs. 3, 4 and Table 1), which consistence with parallel studies on Larrea tridentate, Pinus raeda and eight desert plant species (Hacke et al., 2000; Hamerlynck et al., 2000; Sperry and Hacke, 2002). The driving force for liquid water from soil to and through roots, plant vascular, and eventually evaporates in the sub-stomata cavities of leaves is water potential gradient (Campbell and Norman, 1998). The water potential gradient from soil (represented by predawn water potential) to leaf (symbolized by midday leaf water potential) was relative stability and high in sandy soil in our trial days. However, in heavy textured soil the water potential gradient was low and lost during the extremely drought period (Fig. 3). As a result, population in heavy soil suffered severer water stress than that of sandy soil when significant water deficits occurred on 4 July 2005 and 5 August 2006 due to prolonged drought without rainfall. The WSIS was impressively higher at heavy site than at sandy site in the most of months in the two growing seasons, which further verification the better water condition in the sandy site. The exception of the same value of WSIS at the both sites in August 2005 was attributed to the relative rich rainfall which shielded the influence of soil texture on soil water availability (Fig. 4). Plants in sandy soil experiencing better water status than that in heavy textured soil were not only the results of low 
soil evaporation but also mainly the deeper root systems, larger root surface areas and higher root:leaf surface area ratio than in heavy textured soil $(\mathrm{Xu}$ and Li, 2008).

The overall plant hydraulic resistance $\left(\mathrm{R}_{\text {plant }}\right)$ and leaf specific hydraulic resistance $\left(R_{p}\right)$ were the same at the both sites (Table 1 and Fig. 7). The proportion of the hydraulic resistances of each plant part was also the same between sites during the Augusts of the two years (Fig. 7). Namely, the hydraulic resistances above and below ground were equally important to plant water transport system at the both sites. The significant correlation between the overall plant hydraulic resistance and root hydraulic resistance (Fig. 8), confirmed the root as an organ highly sensitive to the changes in environmental factors like water availability and plant growth rhythm. This is in accordance with recent study result which confirmed roots play an important role in determining the whole plant water balance (Nardini et al., 2003). Based on above discussion and the close correlation between maximum transpiration and leaf specific hydraulic resistance (Fig. 5), we proposed that root hydraulic resistance was a major factor in control plant transpiration rate. Although, there were no significant variation of hydraulic resistance components between dry and wet August at the both sites, $R_{\text {root }}$ increased and $R_{\text {shoot }}$ decreased in dry August, 2006. Because $R_{\text {root }}$ derived from equation 3 included the resistance of the soil-to-root pathway, it was possible that the measured $R_{\text {root }}$ was due to the increase of $\mathrm{R}_{\text {soil }}$. Decrease in leaf area per branch and branch growth rate in August 2006 (Zou et al., 2009) were responsible for the descent of $\mathrm{R}_{\text {shoot }}$. Apparently, the leaf shedding led to the decrease of hydraulic resistors, and thus shoots hydraulic resistance declined. Comparing with the wet August 2005, the stomata

\section{References}

Addington R N, Donovan L A, Mitchell R J, et al. Adjustments in hydraulic architecture of Pinus palustris maintain similar stomatal conductance inxeric and mesic habitats. Plant, Cell and Environment, 2006, 29: 535-545.

Albaugh T J, Allen H L, Dougherty P M, et al. Leaf area and above- and belowground growth responses of Loblolly pine to nutrient and water additions. Forest Science, 1998, 44: 317-328.

Alizai H U, Hulbert L C. Effects of soil texture on evaporative loss and available water in semi-arid climates. Soil Science, 1970, 110: 328-332.

Amodeo G, Dorr R, Vallejo A, et al. Radial and axial water transport in conductance at noon showed downward adjustment to limited maximum transpiration at the both sites in the dry August, 2006 (Table 2). Namely, the decreased root hydraulic resistance, especially in the root-soil interface preventing the water outflow from root to soil (North and Nobel, 1997), combined with the stomata limitation may have facilitated the plant at heavy site to survive under extreme water deficit. Such hydraulic coordination may also function together with morphology adjustment, namely the suspending leaf growth and even shedding of leaves (Zou et al., 2009), to facilitating the survival of plants under extreme drought.

To extract and use water successfully, plants that exist across a range of habitats must make adjustment in hydraulic architecture to maintain hydraulic compatibility between plants and environments (Addington et al., 2006). Understanding hydraulic architecture of the plant can not only deepen our study in classic plant water relations but also provide new insight in plant adaptation to limiting environmental factors. More detailed research should carry out on plant water resistance components of $H$. ammodendron at both vascular and non-vascular system and from tissues to organs levels, and at different time scales, which will finally facilitate better interpreting and predicting the future of $H$. ammodendron under the background of climate changes.

\section{Acknowledgements}

This research was supported by the National Natural Science Foundation of China (40971042) and the Western Light project of the Chinese Academy of Sciences (XBBS 200808). We thank all the staff at Fukang Station of Desert Ecology for their indispensable help in laboratory analysis and field sampling.

the sugar beet storage root. Journal of Experimental Botany, 1999, 50: $509-516$.

Aranda I, Castro L, Pardos M, et al. Effects of the interaction between drought and shade on water relations, gas exchange and morphological traits in cork oak (Quercus suber L.) seedlings. Forest Ecology Management, 2005, 210: 117-129.

Campbell G S, Norman J M. Introduction to Environmental Biophysics. 2nd ed. New York: Springer-Verlag Inc., 1998. 139-144.

Cohen Y, Fuchs M, Cohen S. Resistance to water uptake in a mature citrus tree. Journal of Experimental Botany, 1983, 34: 451-460.

Cruiziat P, Cochard H, Améglio T. The hydraulic architecture of trees: 
main concepts and results. Annals of Forest Science, 2002, 59: $723-752$.

Ewers B E, Oren R, Sperry J S. Influence of nutrient versus water supply on hydraulic architecture and water balance in Pinus taeda. Plant, Cell and Environment, 2000, 23: 1055-1066.

Hacke U G, Sperry J S, Ewers B E, et al. Influence of soil porosity on water use in Pinus taeda. Oecologia, 2000, 124: 495-505.

Hamerlynck E P, McAuliffe J R, Smith S D. Effects of surface and sub-surface soil horizons on the seasonal performance of Larrea tridentata (creosotebush). Functional Ecology, 2000, 14: 596-606.

Henzler T, Waterhouse R N, Smyth A J, et al. Diurnal variations in hydraulic conductivity and root pressure can be correlated with the expression of putative aquaporins in the roots of Lotus japonicus. Planta, 1999, 210: 50-60.

Hernández E L, Vilagrosa A, Luis V C, et al. Root hydraulic conductance, gas exchange and leaf water potential in seedlings of Pistacia lentiscus L. and Quercus suber L. grown under different fertilization and light regimes. Environmental and Experimental Botany, 2009, 67: 269-276.

Iro S, Sakuta K, Gyokusen K. Distribution of hydraulic resistance in seedlings, sprouts and an adult tree of Pasania edulis makino. Ecological Research, 1995, 10: 143-149.

Jury W A, Gardner W R, Gardner W H. Soil Physics. New York: John Wiley, 1991. 328.

Li Y, Xu H, Cohen S. Long-term hydraulic acclimation to soil texture and radiation load in cotton. Plant, Cell and Environment, 2005, 28: 492-499

Meinzer F C. Co-ordination of vapour and liquid phase water transport properties in plants. Plant, Cell and Environment, 2002, 25: 265-274.

Mishio M, Yokoi Y. A model for estimation of water flow resistance in soil-leaf pathway under dynamic conditions. Journal of Experimental Botany, 1991, 42: 541-546.

Nardini A, Ghirardelli L, Salleo S. Vulnerability to freeze stress of seedlings of Quercus ilex L.: an ecological interpretation, Annual Science Forrest, 1998, 55: 553-565.

Nardini A, Lo Gullo M A, Salleo S. Competitive strategies for water availability in two Mediterranean Quercus species. Plant, Cell and Environment, 1999a, 22: 109-116.

Nardini A, Pitt F. Drought resistance of Quercus pubescens as a function of root hydraulic conductance, xylem embolism and hydraulic architecture. New Phytologist, 1999b, 143: 485-493.

Nardini A, Salleo S, Andri S. Circadian regulation of leaf hydraulic conductance in sunflower (Helianthus annuus L. cv Margot). Plant, Cell and environment, 2005, 28: 750-759.

Nardini A, Salleo S, Trifilò P, et al. Water relations and hydraulic characteristics of three woody species co-occurring in the same habitat. Annual Forest Science, 2003, 60: 297-305.

Nilsen E T, Orcutt D M. Physiology of Plants under Stress. New York: John Wiley \& Sons Inc., 1996.

North G B, Nobel P S. Root-soil contact for the desert succulent Agave deserti in wet and drying soil. New phytologist, 1997, 135: 21-29.

Noy-Meir I. Desert ecosystems: environment and producers. Annual Review of Ecology Systematics, 1973, 4: 23-51.

Pyankov V I, Black J, Artyusheva E G, et al. Features of photosynthesis in Haloxylon species of Chenopodiaceae that are dominant plants in Centran Asia desert, Plant Cell Physiology, 1999, 40: 125-134.

Raimondo F, Trifilò P, Lo Gullo M A, et al. Effects of reduced irradiance on hydraulic architecture and water relations of two olive clones with different growth potentials. Environmental and Experimental Botany, 2009, 66: 249-256.

Salleo S, Nardini A, Lo Gullo M A, et al. Changes in stem and leaf hydraulics preceding leaf shedding in Castanea sativa L. Biologia Plantarum, 2003, 45(2): 227-234.

Solari L I, Johnson S, Dejong T M. Hydraulic conductance characteristics of peach (Prunus persica) trees on different rootstocks are related to biomass production and distribution. Tree Physiology, 2006, 26: $1343-1350$

Sperry J S. Hydraulic constrains on plant gas exchange. Agricultural and Forest Meteorology, 2000, 104: 13-23.

Sperry J S, Adler F R, Campbell G S, et al. Limitation of plant water use by rhizosphere and xylem conductance: results from a model. Plant, Cell and Environment, 1998, 21: 347-359.

Sperry J S, Hacke U G. Desert shrub water relations with respect to soil characteristics and plant functional type. Functional Ecology, 2002, 16: 367-378.

Trifilò P, Raimondo F, Nardini A, et al. Drought resistance of Ailanthus altissima: root hydraulics and water relations. Tree Physiology, 2004, 24: 107-114.

Trubat R, Cortina J, Vilagrosa A. Plant morphology and root hydraulics are altered by nutrient deficiency in Pistacia lentiscus. Trees, 2006, 29: 2153-2167.

Tyree M T, Ewers F W. The hydraulic architecture of trees and other woody plants, New Phytologist, 1991a, 119: 345-360.

Tyree M T, Snyderman D A, Wilmot T R, et al. Water relations and hydraulic architecture of a tropical tree (Schefflera morototoni). Plant Physiology, 1991b, 96: 1105-1113.

Tyree M T, Velez V, Dalling J W. Growth dynamics of root and shoot hydraulic conductance in seedlings of five neotropical tree species: scaling to show possible adaptation to differing light regimes. Oecologia, 1998, 114: 293-298.

Tyree M T. Water relations and hydraulic architecture. In: Francisco I P, Fernando V. Functional Plant Ecology. Boca Raton, London, New York: CRC Press, 2007. 118-189.

Vertovec M S S, Ozturk M, Salleo S, et al. Diagnosing plant water status as a tool for quantifying water stress on a regional basis in Mediterranean drylands. Annual Forest Science, 2001, 58: 113-125.

$\mathrm{Xu}$ G Q, Li Y. Rooting depth and leaf hydraulic conductance in the xeric shrub Haloxylon ammodendron growing at sites of contrasting soil texture. Functional Plant Biology, 2008, 35: 1234-1242.

Zimmermann M H. Hydraulic architecture of some diffuse-porous trees. Canadian Journal of Botany, 1978, 56: 2286-2295.

Zimmermann M H, Sperry J S. Anatomy of the palm raphis excelsa IX. Xylem structure of the leaf insertion. Journal of Arnold Arbor, 1983, 46: $160-180$.

Zou T, Li Y, Xu H, et al. Responses to precipitation treatment for Haloxylon ammodendron growing on contrasting textured soils. Ecology research, 2009 (published online). 